DOI: 10.17707/AgricultForest.62.2.09

\author{
Marina NACKA, \\ Nenad GEORGIEV, Ana SIMONOVSKA ${ }^{I}$
}

\title{
YOUNG CONSUMERS' PREFERENCES FOR MACEDONIAN WINE
}

\begin{abstract}
SUMMARY
Macedonian strategy for viticulture and wine production singles out young consumers as a target group of consumers for further increase of the production value and development of wine culture. Therefore, we aim to determinate the presence of young population on the Skopje Wine Winter festival in 2014 and to understand their preferences towards domestic wine and its quality. We performed structured questionnaires to 420 visitors and segmented young consumers as a focus group. We used conceptual model for analysis of consumer attitudes and Chi2-test in Stata 12.0 and StataCorp 2011, for testing the hypotheses for the consumers' perception of quality wine. The results showed that younger consumers were the most present category on the Wine festival. In general, they do not differ from other age groups in terms of their preferences for domestic quality wine, except that this category showed readiness to pay a higher price for domestic quality wine. The quality perception of domestic wine is satisfactory, which creates an opportunity for the wineries to target and to promote their wine to the new segments of young consumers, committed to purchase domestic wine.
\end{abstract}

Keywords: young consumers' preferences, domestic wine, quality perception.

\section{INTRODUCTION}

Wine industry has a strategic importance for the Republic of Macedonia because of $70 \%$ export orientation; growing development trend; high specialization (Balassa index 3.83, Nacka, 2011) and positive trend of investment in sophisticated equipment and marketing skills (CBI, USAID, 2012).

In the next period, an intensive development and wine positioning through building a competitive brand is expected, thus increasing the perception of domestic consumers for quality wines and brands (National Strategy for Viticulture and Wine production (NSVW), 2014-2020).

According NSVW, 2014-2020, the wine market in the country has two consumer groups: middle-aged who have lower purchasing power and consume larger quantities of cheaper wine and younger to middle-aged with higher purchasing power who prefer smaller quantities of high-quality wine. The first group of consumers belongs to the population that normally produces wine for

\footnotetext{
${ }^{1}$ Marina Nacka (corresponding author: marina.nacka@fznh.ukim.edu.mk), Nenad Georgiev, Ana Simonovska University St. Cyril and Methodius, Faculty of Agricultural Sciences and Food, Skopje, MACEDONIA,

Notes: The authors declare that they have no conflicts of interest. Authorship Form signed online.
} 
personal use and it is not a target group that could influence on raising the domestic production value. Therefore, a growing number of wine producers direct to the second groups of consumers as a focus group for further increase of the production value and development of wine culture (NSVW 2014-2020).

In this regard, the aim of the research is to determinate the presence of young population at the Skopje Winter wine festival in 2014. Additionally, the research focused on understanding the consumer preferences towards domestic wine and their perception of quality, related to future strategies for creating recognizable domestic wine brands. In the following section, the theoretical framework overview the quality perception related to the theory of information and possibilities of avoiding the information asymmetry. The results are presented through analysis of consumers' preferences for domestic quality wine and more detailed analysis for the younger consumers as the most present group at the festival. Finally, by comparing the different age categories, the main discussion and conclusions about younger consumers' preferences for domestic quality wine are drawn.

\section{Theoretical framework}

The perception of quality is directly related to the theory of information asymmetry (Wankhade and Dabade, 2010). Factors that lead to information asymmetry and quality uncertainty are associated with:

1. Socio-economic situation and culture of the population (education, culture, national economy and global/national legislation) and

2. Marketing strategies (quality, supply chain management, reputation, advertising, guarantee/warranty).

In transition countries and developing countries there is a possibility of more pronounced presence of low-quality products, which can be attributed to the high presence of information asymmetry and low presence of information symmetry (Wankhade and Dabade, 2010).

Often in these countries, a large number of the population is information asymmetric and assume the price of the product as an average of the high-quality or low-quality product. In those conditions, the expected price become an average price, and part of the population takes into account the expected price that is lower than the costs or the price of the high-quality product. This leads to directing asymmetric consumers towards low-quality products. On the other hand, part of the population is information symmetric and recognizes the quality/price ratio. They consider the concept of a higher price for a high-quality product.

The theory of information asymmetry assumes that the market share of low-quality products is proportional with the growing number of buyers who are information asymmetric. The market share of high-quality products is lower, while at the same time is related to the smaller degree of prevalence of information symmetry. 


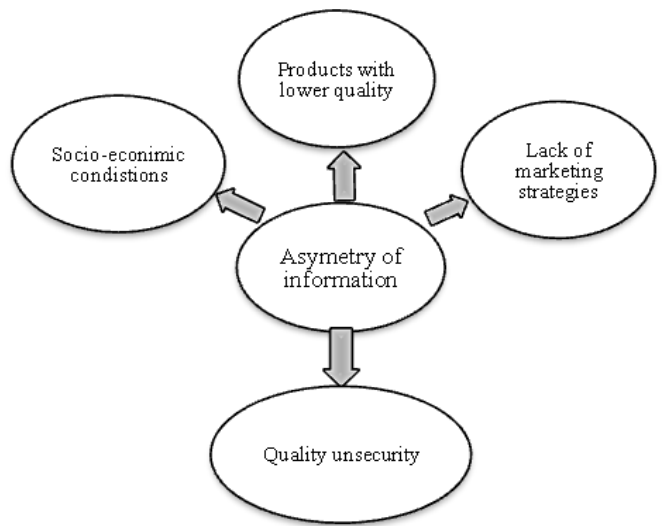

Picture 1 Mechanism for quality uncertainties

Source: Wankhade and Dabade, 2010

The theory of information considers information asymmetry that appears between the producer and consumer as a reason for market failure. It arises from the producer perspective about product characteristics and consequently the lack of knowledge and identification by the consumer, due to lack of easy access to information (Ackerlof, 1970).

Nelson, (1970) characterizes the agri-food market in three product categories, depending on how the information is transmitted to the consumers:

Table 1 Product categories depending on the access to information

\begin{tabular}{|c|c|}
\hline search goods & $\begin{array}{c}\text { Consumer is trying to determinate the product } \\
\text { quality before he buys, through inspection and } \\
\text { research }\end{array}$ \\
\hline experience goods & $\begin{array}{c}\text { Consumer determinates the product quality } \\
\text { after purchase, through use and experience }\end{array}$ \\
\hline credence goods & $\begin{array}{c}\text { Neither previous inspection nor further use is } \\
\text { enough to determinate the quality (e.g. information on } \\
\text { chemical and nutritional composition) }\end{array}$ \\
\hline
\end{tabular}

Source: Nelson, 1970

Ari-food commodities often belong to the second category - experience goods, because of the consumer motivation to form their opinion based on product attributes (mostly taste). However, due to differences in consumers' preferences, the product can be classified into various categories, depending on whether the consumer is interested in the price or other the product characteristics. If other characteristics are compared to the price, the product can be classified as experience good. If the consumer is interested in other characteristics of the production process, the product can be classified as credence goods. The difference between the consumers is the basic of market segmentation and the product differentiation strategy of the enterprises (Rangnekar, 2004). 


\section{MATERIAL AND METHODS \\ Data collection and conceptual model}

The data collection was performed at the Winter Wine festival in Skopje, 2014, which was a closed type event for segmented group of consumers. The method included "face-to-face" interviews with structured questioners to 420 consumers. The questions contain demographic information and questions about consumer perception of product quality and quality/price ratio (Brewerton and Millward, 2001).

Following the Herman and Teuber method (2011), the questionnaire was based on the conceptual model for analysis, presented in picture bellow.

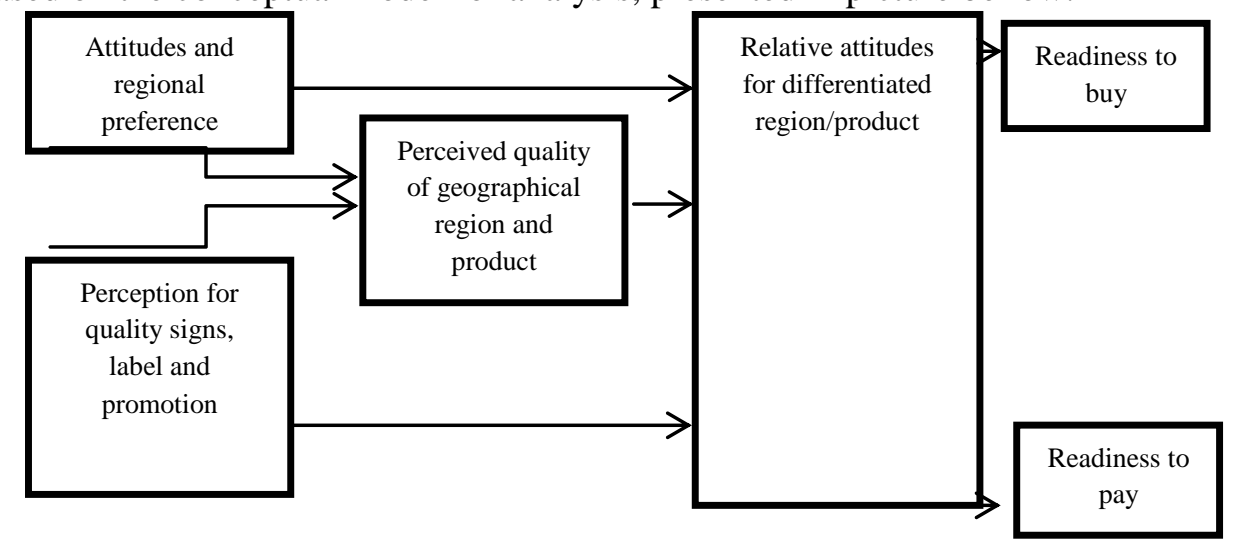

Picture 2 conceptual model for analysis of consumer attitudes (adapted model of herman and teuber, 2011)

The data were presented in nominal and ordinal scale (likert scale with five level of intensity), statistically processed in stata 12.0.

\section{Testing of the hypotheses}

The hypotheses in the research were tested by using chi2-test in stata 12.0, statacorp, 2011. The null hypothesis was tested through several alternative hypotheses, i.e. By crossing of multiple variables corresponding to the hypothesis. Alternative hypotheses show that the results are obtained by the different populations of the sample, while the null hypothesis shows that there is no difference between the different treatments. In this case, the working, or the alternative hypothesis indicated that there is a difference in the types of customers (younger consumers versus older, consumers with higher incomes versus those with lower incomes, consumers with higher education versus those with lower education, etc.) And the perception for the quality of the wine. Otherwise, the null hypothesis asserted that there are no differences between the type of consumers and all differences are observed within the random error.

$\mathrm{H} \mathrm{1}$ 1: younger consumers require quality wine as opposed to other age categories

$\mathrm{H}$ 1.1: younger consumers drink better quality wine 
H 1.2: younger consumers are well informed about quality wine with geographical origin

H 1.3: young consumers buy wine with higher price

H 1.4: young consumers buy domestic wine

H 1.5: marketing has more influence on young consumers.

\section{RESULTS AND DISCUSSION}

The survey was conducted on 420 consumers. Additionally, detailed analysis were performed to the young consumers (18-27 years) which, according NSVW 2014-2020, are targeted group for increasing the value of domestic wine production. The most present age categories of consumers at the Wine festival were those from 18-27 to 28-37 years. The larger percentage of the consumers have personal monthly income from 30000 to $60000 \mathrm{MKD}(24.1 \%)$ and 15000 to $20000 \mathrm{MKD}(23.4 \%)$ and have gained faculty degree $(68 \%)$.

Table 2 Short descriptive preview of variables with highest percentage of the answers

\begin{tabular}{|c|c|c|c|}
\hline Variables & Percentage & Variables & Percentage \\
\hline $\begin{array}{l}\text { Most presented: } \\
18-27 ; 28-37 \text { years }\end{array}$ & $>70 \%$ & $\begin{array}{l}\text { Price range: } \\
\text { From } 150 \text { to } 300 \mathrm{MKD} \\
\text { From } 300 \text { to } 600 \mathrm{MKD} \\
\text { From } 600 \text { to } 1000 \mathrm{MKD}\end{array}$ & $\begin{array}{l}21.8 \% \\
41.2 \% \\
24,0 \%\end{array}$ \\
\hline $\begin{array}{l}\text { Income: } \\
15000-20000 \mathrm{MKD} \\
30000-60000 \mathrm{MKD}\end{array}$ & $\begin{array}{l}23.4 \% \\
24.1 \%\end{array}$ & $\begin{array}{l}\text { With increase of the income: } \\
\text { Would buy wine with higher price } \\
\text { Would buy the same wine }\end{array}$ & $\begin{array}{l}50,1 \% \\
48,2 \%\end{array}$ \\
\hline Higher education & $68 \%$ & $\begin{array}{l}\text { Readiness to pay: } \\
\text { Up to } 600 \mathrm{MKD} \\
\text { Up to } 1000 \mathrm{MKD} \text { (15 EUR) } \\
\text { Over } 1000 \mathrm{MKD}\end{array}$ & $\begin{array}{l}25,8 \% \\
30,73 \% \\
11,33 \%\end{array}$ \\
\hline $\begin{array}{l}\text { Frequency of buying } \\
\text { wine: } \\
\text { Once a week }\end{array}$ & $272 \%$ & $\begin{array}{l}\text { Direct relation of quality/price } \\
\text { ratio } \\
\text { (Information symmetric } \\
\text { population) }\end{array}$ & $71,3 \%$ \\
\hline $\begin{array}{l}\text { Motive: } \\
\text { Personal satisfaction }\end{array}$ & $82.5 \%$ & \begin{tabular}{|l|} 
Importance while buying wine: \\
Brand \\
Region \\
Country
\end{tabular} & $\begin{array}{l}50 \% \\
26 \% \\
27 \%\end{array}$ \\
\hline $\begin{array}{l}\text { Type of wine: } \\
\text { Domestic wine }\end{array}$ & $86.1 \%$ & \begin{tabular}{|l} 
Often buy new wines \\
Same wines \\
Rarely buy new wines
\end{tabular} & \begin{tabular}{|l|}
$51,0 \%$ \\
$27.4 \%$ \\
$199 \%$
\end{tabular} \\
\hline $\begin{array}{l}\text { Location: } \\
\text { Supermarket }(0,251)\end{array}$ & $663 \%$ & $\begin{array}{l}\text { How to be improved the } \\
\text { domestic consumption? } \\
\text { Better promotion of domestic } \\
\text { wines }\end{array}$ & $34.1 \%$ \\
\hline $\begin{array}{l}\text { Region: } \\
\text { Tikves wine district } \\
\text { Povardaski region }\end{array}$ & $\begin{array}{l}80 \% \\
8 \%\end{array}$ & & \\
\hline
\end{tabular}

Additionally, the consumer segment that buys quality wine (table wines with geographical indication, wine with controlled origin and wine with controlled and guaranteed origin) has been selected. These consumers buy wine once a week from the supermarket. Their motive is personal satisfaction. 
Consumers are more dedicated to the domestic wines from Tikves wine district and Vardar River Valley wine region. This segment of consumers separates mostly from 300 to 600 MKD for wine (5-10 EUR), but for good quality of wine have showed readiness to pay from 600 to 1,000 MKD (10-15 EUR).

Furthermore, the results include the perception of the consumers about the impact of logos and quality signs, in the process of wine purchase. The intensity of the impact of the specific logo for quality and the awards placed on the bottle, in the highest percentage (32\% and 29\%) have intermediate level of significance (ranked third out of five levels of significance). The consumers have shown a high awareness of quality, where $38 \%$ determinate the importance of quality with the highest level of importance, as opposed to product price.

According the theory of information asymmetry, this result indicates information symmetric population that recognizes the quality/price ratio. In this case, the market share of high quality products is lower and in the same time proportional to the information symmetry (Wankhade and Dabade 2010). In terms of information asymmetry, the theory (Ackerlof, 1970) presents the product risk and consequences of not satisfying the consumer expectations and consequently a tendency for paying a higher price as a quality indicator. This may result in a reduction of the quality supply and extrusion of high-quality products from the market, thus facing unfair competition. The use of appropriate logos may impact the asymmetry, as mechanisms for quality guarantee or building reputation (Ackerlof, 1970). For the segmented consumers present at the Winter Wine festival, the specific logos for quality and awards have a secondary influence. Basically, it proved the intensive impact of the quality logos on the perception of consumers, which justifies their use as marketing tool for building reputation and quality assurance.

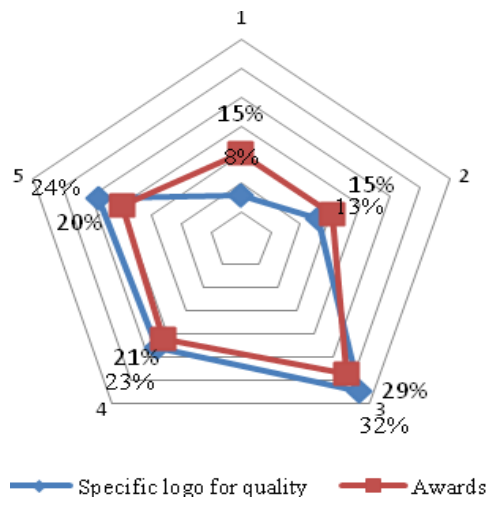

Figure 1 Intensity of the impact of quality sighs in the buying process Figure 2 Importance of the wine quality vs. price of the wine 
Furthermore, by testing hypothesis, the attitudes and perceptions of young consumers were analyzed, taking into account the consumers' age group from 18-27 years, the socio-economic and the marketing- factors influence.

Table 3. Hypothesis tested for younger consumers 'perspective.

\begin{tabular}{|c|c|c|}
\hline Sub-hypothesis & Ho & $\mathrm{Ha}$ \\
\hline H 1. 1: better quality wine & + & - \\
\hline H 1.2: quality wine with geographical origin & + & - \\
\hline H 1. 3: higher price & - & $t^{*}$ \\
\hline H 1.4: domestic wine & + & - \\
\hline H 1. 5: marketing & + & - \\
\hline
\end{tabular}

* $\mathrm{P}<.05 ; * * \mathrm{P}<.01 ; * * * \mathrm{P}<.001$

The first hypothesis concerned the demand of the younger consumers for better quality wine than other age categories. By accepting the null hypothesis, is confirmed that younger consumers more likely to buy better quality wine with geographical origin, but also other age categories, although in small proportion, are an important category of consumers who buy quality wine with geographical origin. In addition, the null hypothesis is accepted in terms of perceiving the reputation of the geographical region as a sign of quality. It states that the young population, although most present of wine event, do not stand out statistically from the other age categories in terms of awareness of the importance of recognized geographical region and its quality.

The results of the third sub-hypothesis, analyzed the wine purchase with a higher price, by the young population. In this case, alternative hypothesis was accepted with significance level of 0.05 , which indicated the difference between the age categories, where younger population has shown readiness to buy quality wine with higher price. In addition, the analysis showed that younger consumers mostly prefer domestic wines, but, the other age categories are also segments that require domestic wine, with geographical origin. Marketing, such as, advertising and promotion of wineries have no particular impact during the wine purchase, neither for the younger consumer segment nor for the other age categories.

\section{CONCLUSIONS}

Consumers are the final users that valorize the market value and the quality of the wine. Their perception of the quality of wine and geographical origin is highly influenced on the socio-economic factors, such as level of income and education. Overall, consumers with higher income and higher level of education require better quality wine with geographical origin, taking in to account its importance. Consequently, they are ready to pay a higher price for domestic wine whose quality is defined through the geographical origin. The highest impact on the process of wine purchase has the price of the product and 
the perception of the brand. However, the size and homogeneity of the domestic market impact on insufficient commitment of domestic wineries to the domestic consumers. It indicates the relative homogeneity of the domestic market, the lack of different assortment and the low purchasing power of domestic consumers. Consumers are well informed only for two wine regions in the country (Tikves wine distinct and Vardar River Valley region) as well as for the wineries with a long tradition and presence on the market.

The most present category at the Winter Wine festival was the younger consumers, which are defined by the wineries as a potential focus group for increasing the value of the domestic production and development of the domestic market. However, compared to other age categories, younger consumers do not differ much as a separate segment in their demands for better quality domestic wine with geographical origin. The younger consumers differ only in their readiness to pay a higher price for quality domestic wine, which is significant for the development of the wineries' strategies intended for this segment of consumers.

If the National strategy for viticulture and wine production emphasizes the younger consumers as focus group for further increase of the wine culture, then better promotion of domestic wines and education of young consumers is of great importance. This would raise the consumers' awareness and perception of the wine quality, significant for improvement of domestic quality wines consumption.

\section{REFERENCES}

Akerlof A. G. (1970). The market for Lemons: Quality, uncertainty and themarket mechanism. Quarterly Journal of Economics, 84 (August) : 488-500.

Brewerton P., Millward L. (2001). Organizational Researh methods: A Guide for students and researchers, SAGE Publications, London.

CBI, USAID AgBiz, (2012). Macedonia's wine sector export marketing plan for EU markets.

Herrmann R., Teuber R. (2011). The Oxford Handbook of the Economics of Food Consumption and Policy, Oxford University Press, Oxford, pp. 881-842.

Nelson P. (1970). Information and consumer behaviour. Journal of PoliticalEconomy, 78 (MarchApril) : 311-329. North, 1990.

OECD, Organisation for Economic Co-operation and Development (2000). Appellations of origin and geographical indications in OECD Member countries: Economic and legal implications. Working Party onAgricultural Policiesand Markets of the Committee for Agriculture JointWorking Party of the Committee for Agriculture and the Trade Committee.

Rangnekar D. (2004). The Socio-Economics of GI, A Review of Empirical Evidence from Europe, UNCTAD-ICTSD Project on IPRs and Sustainable Development, Issue Paper No. 8).

Wankhade L., Dabade B. (2010). Quality Uncertainty and Perception Information Asymmetry and Management of Quality Uncertainty and Quality Perception, Physica Verlag Heidelberg, Springer.

МЗШВ (2014). Стратегија за лозарство и винарство 2014-2020, МЗШВ.

Нацка М. (2011). Маркетинг и конкурентност на виното од Република Македонија од аспект на индустриската сопственост, Магистерски труд, Факултет за земјоделски науки и храна, Скопје. 